\title{
Love, satisfaction and exhaustion in the nursery: methodological issues in evaluating the impact of Work Discussion groups in nursery ${ }^{1}$
}

\author{
Peter Elfer; Sue Greenfield; Sue Robson; Dilys Wilson; Antonia Zachariou ${ }^{2}$
}

Keywords: Emotion; nursery; practitioner; professional reflection; evaluation; work discussion.

\begin{abstract}
The significance of practitioners' emotions in nursery interactions is evident in vivid accounts from widely different socio-cultural contexts. Work Discussion (WD) is a model of professional reflection distinctive in its attention to emotion in work interactions. Psychoanalytic conceptions, particularly the notion of the defended subject, underpin WD. Enabling participants in WD to discuss subjective work experience in an open way is thus subtle and sensitive.
\end{abstract}

Research has not addressed how the impact of different models of professional reflection may be evaluated. Can WD, with its explicit attention to the emotions evoked at work, strengthen practitioners' engagement with children and families?

This paper critically discusses the complex methodological issues in evaluating the impact of WD on nursery practitioners, children and parents in nursery. The challenge is to combine the intense subjectivity of WD with an evaluation that is rigorous and objective. Later papers will illustrate data analysis and report findings.

\section{Introduction}

Defining emotion is difficult but we follow Burkitt in saying that emotions:

...cannot be reduced to biology, relations or discourse alone, but belong to all these dimensions as they are constituted in on-going relational practices. As such, the objects of our study in the sociology of emotions cannot be understood as 'things' but are complexes composed of embodied, interdependent human existence. (1997, p.42).

Vivid descriptions of the significance of emotion in nursery ${ }^{3}$ interactions appear increasingly in the literature. In Brazil, Cardenal describes anger and division between two groups of practitioners:

The nursery staff, Maria and Ana...were very worried about lara, a nine-month-old infant, looked after by them between $11 \mathrm{am}$ and $6 \mathrm{pm}$, who slept for long periods during the morning. Maria, who was initially very upset and angry, believed the staff group in the morning shift did not share the same approach as the group in the afternoon...Maria felt that this disturbed lara in such a way that she preferred to isolate herself and sleep (Cardenal 2011, p.247).

In England, Page has shown parents' desire for practitioners to love their child:

\footnotetext{
${ }^{1}$ This work was supported by the Froebel Trust with a major grant (Grant Number RCH-07-2016).

${ }^{2}$ Author order is alphabetical with equal contributions.

${ }^{3}$ We are using the term 'nursery' here to include a wide range of types of day time group care and education for young children outside the domestic home.
} 
Martha: Yes I did, [want someone to love Holly] because when I couldn't be there I wanted to think that somebody was looking out for her, that she wasn't just a number and she wasn't just left to you know wander aimlessly around...l'd have hated to have...a sea of faces and that she just didn't mean anything to anyone. (Page, 2011, p.317)

In Austrian nurseries, Datler and his colleagues have identified the impact of children's distress:

...we were obliged, repeatedly, to witness the experience of how hard and disturbing it is, to be confronted so intimately with the...often catastrophic emotions of very young children....From this point of view, the caregivers' indifferent and reserved behaviour can be understood as an expression of their desire to protect themselves from becoming overwhelmed...(Datler et al 2010, p.82)

In Norway, Lovgren comments on exhaustion:

Nursery practitioners...have the second-worst occupation for work related health problems....the consequences of workers being emotionally exhausted (and eventually burned out) include job withdrawal and lower productivity and effectiveness (Lovgren 2016, p.157).

We think nursery practitioners and researchers have shown great courage in documenting these emotions which can be difficult to acknowledge and express. However, emotions clearly matter to babies, young children, parents and practitioners. This is consistent with the evidence of the fundamental role emotion plays in early development (Trevarthan, 2005; Shuttleworth, 2010; Panksepp, 2013). Given that nursery is now so central in the lives of children and families in so many countries (OECD, 2012) there is an urgent need for research which explores the part played by emotion in nursery interactions in different national and cultural contexts.

This paper is the first in a series reporting on a funded evaluation of Work Discussion (WD) as a model of professional reflection. WD is distinctive in its detailed attention to the role of emotion in nursery interactions. Its underpinning theory is psychoanalytic, including the notion of the defended subject (Hollway \& Jefferson, 2000). This notion has been explained elsewhere (Elfer, 2012) but in summary, refers to a universal human psychic mechanism to keep out of consciousness ideas and thoughts that may be too painful to allow to be conscious. Facilitating WD groups is a highly skilled, subtle and sensitive process. The facilitator has to maintain a clear focus on the subjective in relation to work, and to nurture an environment in which practitioners can discuss their work experience. WD groups are not therapy groups and it would not be appropriate to delve into emotion that is part of deeper life experience. The aim is to think about emotions evoked at work and their impact on children, families and practitioners.

Professional reflection is seen as an essential component of any competent nursery system (Urban et al., 2012; DfE, 2014). There has been a turn of attention to researching different models of professional reflection. Oberhuemer describes a six country European study of models of continuing professional development (CPD) including different models of professional reflection. This study identified a common commitment to the value of CPD but wide variation in its implementation (2013, p.103). The study makes a major contribution to the documenting and theorising of different models of CPD in early years practice. However, so far, research has not 
addressed how the impact of different models of professional reflection may be evaluated. The need for this evidence is supported in a contemporary international review (ECWI, 2018). It seems unlikely that policy makers will prioritise funding for any individual model of CPD, including professional reflection, in the absence of empirical evidence for the impact of that model on specific outcomes for children and families. Evidence of the effectiveness of WD, as one model of professional reflection, could underpin a radical shift in our understanding of emotional engagement in practitioners' interactions with young children and the factors that contribute to both job satisfaction and exhaustion in the nursery workforce.

There have been three broad theoretical approaches to theorising emotion in nurseries. The concept of 'emotional labour' (Hochschild, 1983) has been used to offer a sociological and class analysis of the exploitation of the early years workforce for economic gain (Colley, 2006; Osgood, 2010). Attachment theory has been used to argue for the importance of emotional attachments between nursery practitioners and children (Belsky et al., 2007), although it has been strongly contested by others (Dencik, 1989). Thirdly, there has been renewed attention to the role of psychoanalytic theory, and in particular social defence theory, to the theorising of contemporary organisations (Armstrong \& Rustin, 2015), including nurseries. Theorising WD occurs in this third strand of conceptualising emotion in nurseries.

While the value of attachment interactions in nursery is contested (Dahlberg et al, 2013), strong arguments have been made for their importance (Dalli et al., 2011; Mathers et al., 2014). Curricular frameworks internationally share the expectation that practitioners should enable babies and young children to become emotionally attached to them (Page \& Elfer, 2013). However, there is evidence of the complex emotional demands of responding to the expectations of many different children for intimate attention (Datler et al., 2010; Drugli \& Undheim, 2012; Elfer \& Page, 2015; Page \& Elfer, 2013).

Attending to issues like this in WD forums is highly sensitive, delicate work, entailing the subjectivity of the nursery participants in a way that is ethical, respectful and avoids any sense of judgement or criticism. This paper critically discusses the complex methodological issues in evaluating the impact of WD on nursery practitioners, children and parents in nursery. The challenge is to combine the intense subjectivity of WD with an evaluation that is rigorous and objective. We summarise the data gathered in the fieldwork (see Table 1) to highlight some methodological and ethical issues arising in the research design which is the primary focus of the paper rather than offering findings. Subsequent papers will report on the four broad areas of outcome - the issues brought to the WD groups, the processes of their discussion, the views of practitioners and parents on the value to them and the children of WD, and the impact of WD on practitioner-child interactions.

\section{Work Discussion introduced}

Thinking and talking about work issues and dilemmas is part of the landscape of professional reflection (Bradbury et al., 2010). Workers, in a wide range of professions including doctors, teachers, nursery practitioners, nurses and social workers, dealing with routinely stressful and emotionally charged situations, may 
experience anxiety and risk of burnout unless there are institutional opportunities for their subjective responses to be understood and contained (Armstrong \& Rustin, 2015). The WD model of professional reflection discussed here has been adapted specifically to provide a reflective space for early years practitioners to bring examples from their work with a child and/or family to share and explore their experience with each other.

The essence of the atmosphere of the WD group is the feeling of participants to be able to:

"Tell it like it is" ...it is often a very new experience for people to be encouraged to ....include subjective thoughts and, sometimes, some acutely painful troubling feelings. The atmosphere of acceptance and genuine interest gradually rubs off (Klauber, 2008, p.xxi)

WD groups, led by experienced facilitators, are organised with an agreed time limit and structured to enable each participant in turn to share a practice example. This is usually presented as a detailed written account of a particular issue or difficulty at work as it is experienced by the individual worker (Klauber, 2008). Given the notion of the 'defended subject', this account may exclude those aspects of an individual practitioner's interactions that she or he finds too painful to be able to consciously reflect on them. For example a practitioner may find she or he struggles to relate to a particular child but denies this experience for fear that it is unprofessional or that colleagues will regard it as unprofessional. The pioneering theorist of group processes was Wilfred Bion (Bion, 1959) who argued that in addition to the two life instincts of love and hate, life and death, there was a third instinct to think and to understand (Rustin, 2001, p.209). On this view, there is a tension within individuals and groups between the urge to think and understand and the desire to avoid thinking and understanding where the topic is threatening or stressful.

The aim of WD is therefore to facilitate a process of discussion with additional probing to elicit further thoughts and feelings. This sustains, as Rustin (2008, p.12) suggests, 'an atmosphere of enquiry...so that the unknown can become less unwelcome'. In this way, learning from practice experience may lead to a clearer understanding of interactions and the possible influence of unconscious processes. The challenge of facilitating WD groups is to help the group maintain a manageable level of anxiety so that difficult or contentious issues can be thought about in a way that enables the members of the group to manage their work better. Facilitators must be attentive to how thinking within the group, including the emergence of disagreements, can be sustained. It is easy for a group to shift to a position of avoidance, pretend agreement, or to blame of those outside the group, for example managers or politicians.

An example of such avoidance in a WD session occurred when one practitioner spoke quite suddenly of the experience of having favourites amongst the children although she was clear that one would never allow this to show in day to day work with the children. The group responded with silence and the practitioner who had made this comment was at first outraged at their lack of acknowledgment of what she regarded as the reality of subjective responses to the children and then embarrassed as if she had disclosed a guilty secret. It may seem inevitable that different practitioners will have different personal responses to different children. Yet the group response was clearly that the very idea of this was too difficult to openly discuss. The challenge for the group facilitators is whether to encourage the group to 
think about this issue or to accept the group's implicit decision to refuse to acknowledge it. The former may open up a discussion of how subjectivity can be best managed in professional work but it may also risk a reinforcement of the group's defences on this and other anxiety provoking issues. Allowing the group to move away from the issue on that occasion may enable the group to return to it at another time. The judgement required of the facilitators is whether moving away from the issue is helpful at that point in the group's life, or whether it may re-inforce a sense in the group that difficult work topics must be avoided. A later paper will report on the evaluation of these detailed discussions and processes within individual WD sessions.

\section{The WD intervention in this study}

The fieldwork is taking place in a single local authority. The three main ethnic groups of the local authority are Asian / British Asian (46\%); White (27\%); Black / Black British (18\%). According to rankings of multiple disadvantage, the authority is second highest (most deprivation) of 33 London authorities and second highest of 326 English local authorities (Social Mobility Commission, 2017).

Two WD groups are taking place. Group 1 is a team of nine practitioners working with two year olds in a nursery with National Teaching School (NTS) status. In English education policy, NTS status means that a school has been recognised as a centre of excellence with a record of raising standards in neighbouring settings (NCTL 2017). Group 2 is for managers of nurseries in the catchment area of the NTS. Group 1 is participating in 30 WD sessions, ten each term, at weekly intervals and lasting 75 minutes. Group 2 is participating in 15 sessions, five each term at fortnightly intervals, each lasting 90 minutes. Each session is led by two facilitators, one with early years expertise and one with group relations expertise. The overall aim of the WD with Group 1 is to evaluate the impact of this work in practitioner-child interactions, practitioner-parent relations and practitioners' perceptions of its support to them in their work experience. The causal process proposed is that when practitioners feel their own feelings and thoughts at work are better understood, they will be more able to do this for the children and parents.

\section{Evaluating the contribution of WD: Data collection and instruments}

Evaluation of the WD sessions has run alongside, but entirely separate from, the sessions themselves. The main evaluation data (views of participants, impact on their interactions with children, and impact on interactions with parents) is being collected in the NTS with Group 1. The Group 1 sessions are audio recorded. The views of Group 2 participants are sought and detailed process notes kept but the sessions are not recorded. The reason for this difference is the different aims of the evaluation in Group 1 and Group 2. The research design is based on the idea that if the evaluation from Group 1 shows positive evidence of impact and the managers in Group 2 are positive in their assessment of the value of WD to their work, they will be more likely to implement it and the policy case for a larger scale investment in WD, as complementary to a range of evaluated CPD models, will be stronger.

The data was gathered in four rounds, each lasting one week. The data collected in relation to each WD group is summarised in Table 1. 
Table 1: Work Discussion Group processes and Evaluation Data Collection

\begin{tabular}{|l|l|l|l|l|}
\hline \multicolumn{2}{|l|}{$\begin{array}{l}\text { WD Group 1 } \\
\text { (practitioners working with 2 year olds) ( } n=9)\end{array}$} & $\begin{array}{l}\text { WD Group 2 } \\
\text { (managers of nurseries in } \\
\text { catchment area of main study } \\
\text { nursery) ( } n=6)\end{array}$ \\
\hline & $\begin{array}{l}\text { WD sessions } \\
\text { (see Note 1 for } \\
\text { analysis of } \\
\text { data) }\end{array}$ & $\begin{array}{l}\text { Evaluation } \\
\text { (see Note 2 for analysis of } \\
\text { data) }\end{array}$ & $\begin{array}{l}\text { WD sessions } \\
\text { (see Note 1) }\end{array}$ & Evaluation \\
\hline $\begin{array}{l}\text { Round 1 } \\
\text { January }\end{array}$ & $\begin{array}{l}\text { Audio tapes of } \\
\text { 29 weekly WD } \\
\text { group } \\
\text { sessions. }\end{array}$ & $\begin{array}{l}\text { Video observations of } \\
\text { practitioner-child \& child- } \\
\text { child interactions. } \\
23 \text { children (8m; 15f) aged } \\
2.4-3.1 \text { at start (M=2.9y). }\end{array}$ & $\begin{array}{l}\text { Detailed notes } \\
\text { taken by } \\
\text { facilitators } \\
\text { during 17 }\end{array}$ & \\
\hline
\end{tabular}




\begin{tabular}{|c|c|c|c|c|}
\hline & \multirow{4}{*}{$\begin{array}{l}\text { Immediate post } \\
\text { session review } \\
\text { and record by } \\
\text { the two group } \\
\text { facilitators of } \\
\text { key themes in } \\
\text { content and } \\
\text { process of } \\
\text { discussion. } \\
\text { Independent } \\
\text { reviewer listens } \\
\text { to audio and } \\
\text { facilitators' } \\
\text { review of } \\
\text { alternate } \\
\text { sessions and } \\
\text { adds } \\
\text { commentary. }\end{array}$} & $\begin{array}{l}\text { Interviews with parents } \\
\text { Time } 30 \text { mins } \\
8 \text { parents ( } 1 \text { father, } 7 \text { mothers) }\end{array}$ & $\begin{array}{l}\text { fortnightly WD } \\
\text { group sessions. }\end{array}$ & \\
\hline $\begin{array}{l}\text { Round } 2 \\
\text { March }\end{array}$ & & $\begin{array}{l}\text { Video observations of } \\
\text { practitioner-child \& child- } \\
\text { child interactions. } \\
23 \text { children ( } 8 \mathrm{~m} ; 15 \mathrm{f}) \text { aged } \\
2.4-3.1 \text { at start }(\mathrm{M}=2.9 \mathrm{y}) \text {. } \\
\text { Interviews with } 10 \text { WD group } \\
\text { participants. } \\
\text { Interview length range: } \\
22 \text { mins-58mins. } \\
\text { Interviews with parents. } \\
15 \text { parents ( } 14 \text { mothers, } 1 \\
\text { father) }\end{array}$ & \multirow[t]{3}{*}{$\begin{array}{l}\text { Immediate post } \\
\text { session review } \\
\text { and record by } \\
\text { the two group } \\
\text { facilitators of } \\
\text { key themes in } \\
\text { content and } \\
\text { process of } \\
\text { discussion. }\end{array}$} & $\begin{array}{l}\text { Interviews } \\
\text { with } 7 \text { WD } \\
\text { group } \\
\text { participants. } \\
\text { Interview } \\
\text { length range: } \\
\text { 20mins- } \\
37 \text { mins. }\end{array}$ \\
\hline $\begin{array}{l}\text { Round } 3 \\
\text { July }\end{array}$ & & $\begin{array}{l}\text { Video observations of } \\
\text { practitioner-child \& child- } \\
\text { child interactions. } \\
23 \text { children }(8 \mathrm{~m} ; 15 \mathrm{f}) \text { aged } \\
2.4-3.1 \text { at } \mathrm{start}(\mathrm{M}=2.9 \mathrm{y}) ; \\
6 \text { children }(3 \mathrm{~m} ; 3 \mathrm{f}) \text { aged } 2.7- \\
2.9 \text { at start }(\mathrm{M}=2.8 \mathrm{y}) \text {. } \\
\text { Interviews with } 8 \text { WD group } \\
\text { participants. } \\
\text { Interview length range: } \\
28 \text { mins-59mins. } \\
\text { Interviews with parents. } \\
\text { Time } 30 \text { mins } \\
12 \text { parents }(10 \text { mothers } 2 \\
\text { grandmothers) }\end{array}$ & & $\begin{array}{l}\text { Interviews } \\
\text { with } 5 \text { WD } \\
\text { group } \\
\text { participants. } \\
\text { Interview } \\
\text { length range: } \\
\text { 32mins- } \\
\text { 48mins. }\end{array}$ \\
\hline $\begin{array}{l}\text { Round } 4 \\
\text { November }\end{array}$ & & $\begin{array}{l}\text { Video observations of } \\
\text { practitioner-child \& child- } \\
\text { child interactions. } \\
6 \text { children }(3 \mathrm{~m} ; 3 \mathrm{f}) \text { aged } 2.7- \\
2.9 \text { at start }(\mathrm{M}=2.8 \mathrm{y}) \text {. } \\
\text { Interviews with } 10 \text { WD group } \\
\text { participants. } \\
\text { Interview length range: } \\
37 \text { mins-68mins. } \\
\text { Interviews with parents. } \\
\text { Time } 30 \text { mins } \\
13 \text { parents ( } 13 \text { mothers) }\end{array}$ & & $\begin{array}{l}\text { Interviews } \\
\text { with } 5 \text { WD } \\
\text { group } \\
\text { participants. } \\
\text { Interview } \\
\text { length range: } \\
\text { 39mins- } \\
60 \text { mins. }\end{array}$ \\
\hline
\end{tabular}

Note 1: Analysis of the data on the content and process of the discussions will be discussed in the next paper reporting on this research. The analysis will focus on three themes, the issues and challenges practitioners wanted to discuss; the processes of thinking and discussion; and what WD participants said to the facilitators about whether the value of WD to them.

Note 2: Analysis of the evaluation data (on impact) is discussed later in this paper in the sections relating to the three areas of possible impact (practitioners' interactions with children; parents' views on partnership with the setting; and practitioners' views about the value of WD to them. 
The fundamental question in evaluation research is 'has the intervention ... achieved its anticipated goals?' (Bryman, 2004, p.40). In the current context, has WD supported participants in better management of complex working relationships? Key to addressing such a question is an in-depth understanding of the context and the viewpoints of stakeholders (Bryman, 2004). Urban et al. (2012) also suggest that the participation of all stakeholders in systems of evaluation, monitoring and quality improvement is fundamental to a competent early childhood system. With that in mind, the project focuses on attempting to evaluate the effect of WD on the practitioners, children, and parents and carers. Each of these strands is discussed below, but central to the evaluation is the collection of multiple forms of data, and an approach that supports both qualitative and quantitative analysis. Such mixed methods approaches may be particularly suitable for educational research and evaluation (Cohen, Manion \& Morrison, 2011). In addition, the Team felt that the generation of quantitative data could be of particular value in presenting findings to policy makers, whilst rich qualitative data was also needed to convey the complexities and scope of the children's experiences and behaviour.

Evaluating any project carries with it some inherent challenges, particularly the charge that the evaluators may be committed to its success and their judgements albeit unconsciously, influenced (Camfield, Duvendack \& Palmer-Jones, 2014). Whilst it may be challenging to completely eliminate bias underlying principles for trying to counter bias are being systematic, transparent and reflexive (Camfield et al., 2014 , p.58). In support of these principles, a clear, systematic research plan which outlined all data sources was constructed. All evaluative tools were developed independent of WD facilitators, and no team members facilitating WD sessions were involved in evaluating impact. Careful archiving of all data and full descriptions of the approach to analysis has supported transparency. We have attempted to ensure (and demonstrate) reflexivity by including field notes and personal reflections.

Throughout the project, the Project Director met separately with WD facilitators and evaluators, and joint meetings excluded discussion of data.

A major question is how we can have confidence that any changes in practitioners' actions or in the children, can be attributed to the project, and not the result of other influences, or the children's general development. Cohen et al. assert that it is 'highly unlikely that indisputable causality is ever completely discoverable in the social sciences' (2011, p.54), and this is true here. However, in framing research questions (see the next section), we have attempted to provide the potential for making what are reasonable causal inferences, albeit cautious. Morrison (2009) suggests that the likelihood of making strong causal inferences increases with the number of data collection points, in this case four for the children, and three for practitioners and parents/carers. Cohen, Manion \& Morrison (2011) suggest that qualitative observational data may even have more explanatory potential than numerical data, particularly in what they term the 'real world' of education. At the same time, the data generated here will be subjected to both qualitative and quantitative analysis.

\section{Methodological and ethical issues in interviewing practitioners}

We collected evaluation data through interviews with the practitioners and the managers attending the WD groups. Managing this element of the evaluation meant 
conducting the one-to-one interviews at three times throughout the intervention (see Table 1). The interviews followed a semi-structured interview schedule with the three main research questions being:

1. What were the practitioners/managers expectations and dispositions before the start of the interviews? What are their impressions and level of satisfaction during the intervention?

2. How do the practitioners/managers evaluate the process and the structure of the Work Discussion groups?

3. How do the participants evaluate the impact and helpfulness of the Work Discussion groups?

We had to develop a validated interview schedule. This was informed by previous research on the evaluation of interventions (e.g. Baernstein \& Fryer-Edwards, 2003), on the impact evaluation of professional development programmes (e.g. King, 2014) and research on reflection in education (e.g. Mann, Gordon, \& MacLeod, 2009).

Another significant methodological challenge, which was evident in all the aspects of the project but pertinent in the interviews, was the attrition rate of participants. In the first round of interviews, the interviewees were ten practitioners and seven managers. In the second round, only eight practitioners and five managers were interviewed. In the third round, nine practitioners and six managers were interviewed. Amongst the practitioners, some had attended all the sessions, and some joined the sessions after the official start of the project and as soon as they had started working with the two-year olds. By the beginning of the third term of the project, only four of the practitioners had remained the same from the beginning of the project. This attrition could be attributed to the highly fluid nature of the early years workforce in the England rather than to the participants intentionally leaving the project, and was considered an inevitable development. Future studies in this area could aim to recruit more participants so that by the end of the project, the core of the participants will be comprised of a group of practitioners/managers who have consistently attended the sessions and interviews.

One of the most significant ethical issues that emerged was the practitioners' practice of not referring to children's names in the interviews. This raised difficulties in making links between the practitioners' interviews, the parents' interviews, the children's observations, and the WD sessions, in order to assess the intervention's impact on specific children. From the practitioners' point of view, revealing the children's names in the interviews often appeared as an ethical issue, potentially because children's anonymity and confidentiality is very important in their workplace. Even when we explained to the practitioners that the children's anonymity would be protected in any publications, there was still some hesitation. Whilst the prevalent assumption is that this was for confidentiality reasons, this resistance also raises the question of whether practitioners were consciously or unconsciously employing this approach in an attempt to emotionally distance themselves from the children, at least during the interview. It would therefore be interesting to explore how persistent this practice was throughout the development of the study and up to the study's completion.

Another ethical challenge was the knowledge we had about the practitioners' and managers' ideas/questions regarding the WD groups. The ethical protocols did not 
allow evaluators to share this knowledge with the WD facilitators until completion of the research. This information could have led to the improvement of WD sessions while these were still ongoing. We had to constantly grapple with the question of how ethical it was to know that practitioners would like some changes but not be able to pass that on to the WD facilitators. We had to weigh the importance of disclosing this information with the importance of upholding the ethical protocols. Given that this was clearly not a piece of action research, it was decided that disclosing this information would have potentially distorting effects to the whole project's design. A possible compromise in future maybe to gently encourage practitioners to give feedback directly to the WD group facilitators.

\section{Methodological and ethical challenges in observing the children}

Whilst eliciting the views of practitioners participating in WD is essential, this alone is not sufficient for assessing potential benefits, and a consideration of the possible effect of WD on the children is crucial. What, though, might we look for? The distinctiveness of WD is its inclusion of attention to emotion in work interactions. In addition, young children's personal, social and emotional development is identified as one of the three prime areas of the Foundation Stage in England, 'crucial for igniting children's curiosity and enthusiasm for learning, and for building their capacity to learn, form relationships and survive' (DfE, 2017, p.4). Similarly the relational and affective dimensions of early childhood pedagogy have been emphasised in international reviews of the literature on effective provision (Dalli et al., 2011; Mathers et al., 2014). Thus, attention to the children's affective development, at least, is appropriate. Two other factors also influenced the eventual choice of research approach: 1) the value of an approach which was sensitive to the context of the setting; 2) the project aim of influencing policy and practice.

Initially we looked for pre-existing measures, but concluded that these were unsuitable, generally on the grounds of either their sensitivity to context or their focus, for example, the Sustained Shared Thinking and Emotional Well-being (SSTEW) Scale (Siraj, Kingston \& Melhuish, 2015) focuses on adult interactions with the children. We felt it was important to look at the children's behaviour by themselves and with peers, as well as with adults. As a result, an observation-led framework based on Development Matters in the Early Years Foundation Stage (2012) was developed, using statements in the Personal, Social and Emotional area, and adhering to four of the bands (8-20 months, 16-26 months, 22-36 months, 30-50 months). This spread was in order to ensure that it reflected the likely development of the children during the research. Development Matters, whilst non-statutory, was produced by Early Education in England with support from the Department for Education, and is designed to 'support(s) practitioners in implementing the statutory requirements of the EYFS (Early Years Foundation Stage)' (Early Education, 2012: 1). In so doing, we were mindful of utilising a framework familiar to both practitioners and policymakers, and thus potentially helpful in the project aim of exerting influence on policy and practice in the event of supportive data. This emphasis on starting from curricula sensitive to context also reflects what Urban et al. (2012) emphasise as supportive of democratic legitimacy - a commitment to the use of evaluation tools that have meaning and relevance to practitioners and parents in varying political and socio-cultural contexts. 
Generation of data was structured at set out in Table 1 with a pre-intervention week of observations before WD began. As has already been noted, inferring causality is challenging. In an effort to support what we hope are reasonable, but cautious, causal inferences, the three research questions with regard to the children are:

1 Has this group of children made significantly more progress than could be expected (that is progress significantly beyond that predicted by the agerelated development bands of the EYFS)?

2 Have children who have been the subject of WD made better progress than the cohort as a whole?

3 Have children whose Key Person participated in WD made better progress than those whose Key Person did not?

These questions themselves highlight an ethical and methodological challenge. As noted above, strict separation was maintained between WD facilitators and evaluators, with no sharing of data. However, in attempting to evaluate the effect of WD, it was important to know which practitioners participated, and which children were the subjects of WD. In order to preserve the separation, the names of children and WD participants were given to evaluators at the end of phase 3 , with no details of the discussions which took place.

In each round, observations were recorded over a period of a week using a researcher-operated hand-held camcorder to generate rich, event-driven data on the children. The event-driven nature means that they vary considerably in length, from 23 seconds to 23 minutes 12 seconds, and many feature multiple participant children. Throughout each round, we attempted to record as broad a range of social (child-child, adult-child, child alone) and physical (indoor, outdoor, snack times, sand play, mark-making, construction play, pretend play, etc) contexts as possible. This data is analysed for evidence of each child's behaviour according to the statements derived from the EYFS. For example, does the video data show evidence that a child is 'interested in others' play \& starting to join in', or does the video show that she can 'play in a group, extending \& elaborating play ideas'?, suggesting a difference in a child's current competence in making relationships.

The use of video has the advantage that data can potentially be re-analysed in future using other frameworks, if desired. Video poses a range of ethical and methodological challenges, many well-rehearsed elsewhere (see, inter alia, Flewitt, 2005; Robson 2011a, 2011b; Sørensen, 2014; White, 2017). Here, we focus on two of particular significance in this project: consent; and conflict and distress.

Looking first at consent, the team ensured the consent of all participants for videoing. The British Educational Research Association's (BERA) Ethical Guidelines emphasize that 'Children should therefore be facilitated to give fully informed consent' (2011, p.6). For the children, we began by spending time with them without the camcorder, followed by ensuring they saw the camcorder and could pick it up, but were not yet being videoed. The majority of the children have limited markmaking skills, and we thought it inappropriate to use a form of written consent. Thus, children's verbal consent was initially sought, with episodes played back to children using the camcorder screen so that they could see themselves. Most important, however, was an approach to seeing consent as 'provisional' (Flewitt, 2005), 
continually negotiated and reaffirmed, with children's opportunities to dissent clearly respected (Dockett et al., 2012). This includes attention to body language, gesture and facial expression, as well as verbal dissent. In practice, children are accustomed within the setting to having their activities recorded, and photographs are used extensively as documentation. Many of the children also interacted with the camcorder and researcher, suggesting their familiarity with camcorders. Such interactions included looking at the researcher and camcorder whilst playing, smiling into the camcorder, as well as more direct interactions, such as asking to see what was being filmed, holding up toys to the camera, and even a hand puppet being used to 'eat' the camcorder. Whilst the attention of the researcher could potentially lead to participant reactivity (the so-called Hawthorne effect), spending as much time collecting data in the setting as possible can help children habituate to the observer's presence (Cohen et al., 2011). Hancock, Gillen \& Pinto (2010) found that the effect of being recorded tended to be felt more strongly by adults than children, a finding borne out here. One practitioner commented that it had been good to have the research going on 'but I won't miss that!' she said, pointing at the camcorder.

The second challenge to highlight is an aspect where ethics and methods may potentially be in tension. The project is underpinned by a focus on emotion, and thus it is invaluable to have data which includes a range of the children's emotional experiences. It is axiomatic to say that not all emotional experiences are positive ones, and children may exhibit distress, and also be in conflict with one another or with adults. Even if children do not signal that they wish recording to stop (at such times it is questionable if any of us have sufficient control to do so), the dilemma for the researcher is the extent to which consent may be implicitly withdrawn. Would one, as an adult, want such an episode recorded or viewed? The decision was taken to continue recording in most instances, with a very few episodes being recorded in written note form, but the tension is difficult to resolve. There may also be times (albeit few) when the researcher is compelled to step out of role, and become a more active participant. For example, on one occasion a girl started to drink the contents of a bowl of soapy water that had been used to wash some dirty toys: it was not a difficult to decide it was more important to stop videoing and attempt to intervene, rather than continue recording in order to capture what the girl did next, however interesting that might have been!

\section{Methodological and ethical issues in the interviews with parents}

\section{Parent perspectives: A complex web of power?}

A number of children attending the nursery have been referred by Social Services or Health Services as they have some additional needs. They have not freely chosen to attend the setting but parents are required to bring their children to the setting. This inevitably has an effect on their initial approach to the setting and those who work there. These parents may be wary of appearing to criticise anything in case it has detrimental outcomes for either them or their children. They may feel that they have no power in decision making for their children.

We were particularly conscious therefore of the existence of power in relationships and the way power may be 'dominating meanings'. Power is a relationship of struggle (Belsey, 2002) to dominate the meanings we give to our lives. It is a battle 
to authorise the truth, because truths do not just happen, they are produced in our struggle to decide the meanings of our actions, thoughts and feelings.

(MacNaughton, 2005, p.27; Brooker, 2010, p.181). The existence of this power has an impact on the gathering of the data and subsequently the truths produced by the parents. Examples of this in relation to this research are discussed below.

Parents have the power to hold / withhold information about their circumstances and their children. They are the experts on their children and all the details that they know can make a difference to the ways their children relate to a new setting. It has frequently been demonstrated that where home and setting work together, the outcomes for children are better (Knopf \& Swick, 2007). However, parents only disclose what they want to disclose and they can decide what is important for them and for their children. They can choose whether to attend a session or not BUT there may always be the feeling that whatever they do, there may be consequences for their child.

The practitioners have the power of professional knowledge and the 'protection' of the institution and their colleagues. Their professional bodies decide on expectations and outcomes. They use English as the dominant language. The children have a wide variety of cultures and backgrounds: are these practitioners aware of the effect this may have on language development where English is not the first language? They decide which children will move rooms and who will not; they assess the children to help them make these decisions. They write reports and appear to hold the power in the decision making.

The parents could choose whether to take part in the research or not. However, they may well see us, as researchers, as 'authority figures' who may divulge information to the authorities in the setting or to Social Services or Health Services. It is difficult to explain the researcher role and to be confident of a shared understanding, especially in a range of languages, or to convince them of confidentiality. The researcher's role included decisions about the questions, the use of English for the interviews, and the location for the interviews which was initially a room in the setting. Interestingly when given the choice to meet at the setting or at home, all parents chose the setting.

It is important to consider too how the practitioners perceived the researchers and their presence in the setting. The dates were arranged with the NTS Head and practitioners then distributed interview invitations to the parents, choosing who to invite. They knew some parents well and these may be the ones who were invited (we cannot know if this was the case), but there were other parents who were much less well known or involved. We have to consider the possible impact of this on our findings. There are always some parents who are not known as well or not seen very often in the setting (Swick, 2004) and these may easily be left out.

We wanted to obtain the views of a wide range of parents and not only those who were involved in the NTS or were the parents who 'fit' (Knopf \& Swick, 2007). Two parents interviewed were employed in the setting and others were well known to staff as they have had other children in the nursery or have attended one or more of the extra groups organised by the setting for example English for Speakers of Other Languages (ESOL). These parents were comfortable in the setting and related well to the staff. Other parents who agreed to take part did not arrive at the time agreed 
even though they were telephoned by the receptionist to remind them, indicating the power of parents to make the final decision about participating. These parents certainly come from the 'variety of sociocultural backgrounds' and whose children and identities should be honoured. (Souto-Manning \& Swick, 2006)

Location for the interviews was problematic. All the rooms in the setting were much in demand but an office with two hard chairs and a desk may not be the ideal place for an interview. The setting is one of being 'locked in' or 'locked out' for safety reasons, which means that no one is able to 'wander in'. There is a large reception area and the receptionists are very welcoming. Parents are anxious about any researchers going to their homes. This may be because many are in challenging living conditions and partly because of the lack of trust in 'figures of authority' referred to above.

\section{Conclusion}

Emotion and emotional experience are central to interactions in nurseries. The starting point of this research is that emotions, how they are evoked, managed and their meaning for children and practitioners, are critical in theorising any relational pedagogy. Emotions influence, and are influenced by, nursery culture and ethos, those attitudes and practices, that may not be expressed in written documentation but that are part of the lived collective perception of what can and cannot be said and done.

Whilst children's emotional experiences, both in their own right and in facilitating or inhibiting their agency, exploration and learning, are the primary concern of the paper, the proposal is that they are intimately bound up with the emotions of practitioners and how practitioners manage these. Professional reflection is one way attention can be given to work interactions. However, such forums in the early years care and education sector have not yet developed to give explicit attention to emotional experience as part of professional practice and part of professional discussion. Emotions are a vital component of sensitive and responsive interactions with young children. They are also vital in interactions with family members and with colleagues. Fear of what can be talked about and what is 'off the agenda' is powerful in shaping professional discourse, who is able to contribute and who feels excluded.

This paper has therefore introduced a model of professional reflection called Work Discussion (WD) that is explicitly attentive to emotional experience at work, including the emotional experience of discussing work. If professional reflection is to be given series attention by policy makers, then it is essential that the absence of empirical evidence on the impact of differing models of professional reflection is addressed. This paper has offered a critical discussion of the complex methodological issues in evaluating the impact of WD on nursery practitioners, children and parents in nursery.

\section{References}

Armstrong, D. \& Rustin, M.J. eds. (2015). Social Defences against Anxiety: Explorations in the Paradigm. London: Karnac. 
Baernstein, A., \& Fryer-Edwards, K. (2003). Promoting reflection on professionalism: a comparison trial of educational interventions for medical students. Academic Medicine, 78(7), 742-747.

Belsey, C. (2002). Poststructuralism: A Very Short Introduction. Oxford: Oxford University Press.

Belsky, J., Burchinal, M., McCartney, K., Vandell, D., Clarke-Stewart, K. \& Owen, M.T. (2007). Are There Long Term Effects of Early Child Care? Child Development, 78(2), 681-701.

Bion, W. (1959). Experiences in Groups. London: Tavistock Publications.

Bradbury, H., Frost, N., Kilminster, S. \& Zukas, M. (2010). Beyond Reflective Practice: New Approaches to Professional Lifelong Learning. London: Routledge.

British Educational Research Association (BERA) (2011) Ethical Guidelines for Educational Research, Available at:

http://www.bera.ac.uk/publications/pdfs/ETHICA1.PDF

Brooker,L. (2010). Constructing The Triangle Of Care: Power And Professionalism In Practitioner/Parent Relationships', British Journal of Educational Studies. 58 (2), 181196.

Bryman, A. (2004). (2nd ed.) Social Research Methods. Oxford: Oxford University Press.

Burkitt, I. (1997). Social Relationships and Emotion. Sociology, 31(1), 37-55.

Camfield, L., Duvendack, M. \& Palmer-Jones, R. (2014) Things you Wanted to Know about Bias in Evaluations but Never Dared to Think, IDS Bulletin 45(6): 49-64. http://onlinelibrary.wiley.com. DOI: 10.1111/1759-5436.12112.

Cardenal, M. (2011) Psychoanalytic thinking in the community through Bick's observational method: A Work Discussion Seminar Experience with care workers in nursery. Infant Observation. 14 (3) 245-255.

Cohen, L., Manion, L. \& Morrison, K. (2011) (7 $7^{\text {th }}$ ed.) Research Methods in Education. London: Routledge.

Colley, H. (2006). Learning to Labour with Feeling: class, gender and emotion in childcare education and training. Contemporary Issues in Early Childhood 7 (1), 1529.

Dahlberg, G., Moss, P. \& Pence, A. (2013). Beyond Quality in Early Childhood Education and Care. Languages of Evaluation. $3^{\text {rd }}$ Edition. London: Routledge. 
Dalli, C., White, J., Rochel, J., Duhn, I. et al (2011). Quality early childhood education for under-two-year-olds: What should it look like? A literature review. Ministry of Education, New Zealand.

Datler, W., Datler, M. \& Funder, A. (2010). Struggling against a feeling of becoming lost: a young boy's painful transition to day care. Infant Observation 13 (1). 65-87.

Department for Education (DfE), (2017) Statutory Framework for the Early Years Foundation Stage, Runcorn: Department for Education.

Dencik, L. (1989). Growing Up in the Post-Modern Age: On the Child's Situation in the Modern Family in the Modern Welfare State. Acta Sociologica, 32, (2), 155-180.

Dockett, S., Einarsdóttir, J. \& Perry, B. (2012). Young children's decisions about research participation: opting out. International Journal of Early Years Education, 20(3), 244-56.

Drugli, M.B. \& Undheim, A.M. (2012). Relationships between young children in full time day care and their caregivers: a qualitative study of parental and caregiver perceptions. Early Childhood Development and Care. 182(9)1155-1165.

Early Childhood Workforce Initiative (2018). Strengthening and supporting the Early Childhood Workforce: Training and Professional Development. ECWI. January 2018.

Early Education (2012) Development Matters in the Early Years Foundation Stage (EYFS). London: Early Education.

Elfer, P. 2012. Psychoanalytic methods of observation as a research tool for exploring young children's nursery experience. International Journal of Social Research Methodology 15 (3):225-238.

Elfer, P., \& Page, J. (2015). Pedagogy with babies: Perspectives of Eight Nursery Managers. Early Child Development and Care. Published on line $27^{\text {th }}$ April 2015

Flewitt R., (2005) 'Conducting research with young children: some ethical considerations', Early Child Development and Care, 175(6): 553-65.

Hancock, R., Gillen, J. \& Pinto, G. (2010) 'Using Video Technology', in J. Gillen and C.A. Cameron (eds.) International Perspectives on Early Childhood Research. A Day in the Life, Basingstoke: Palgrave Macmillan, pp.35-58.

Hochschild, A.R. 1983. The managed heart: Commercialization of Human Feeling. Berkeley: University of California Press.

Hollway, W. \& Jefferson, A. (2000). Doing qualitative research differently. Free Association, narrative and the interview method. London: Sage.

King, F. (2014). Evaluating the impact of teacher professional development: an evidence based framework. Professional development in education, 40(1), 89-111 
Klauber, T. Forward in Rustin, M.E. \& Bradley, J. (2008) (eds) Work Discussion: Learning from Reflective Practice in Work with Children and Families. London: Karnac books

Knopf, H. \& Swick, K. (2007) 'How Parents Feel About Their Child's Teacher/School: Implications for Early Childhood Professionals' Early Childhood Education Journal, Vol. 34, No. 4

Løvgren, M. (2016). Emotional exhaustion in day-care workers. European Early Childhood Education Research Journal. 24 (1), 157-167.

Mann, K., Gordon, J., \& MacLeod, A. (2009). Reflection and reflective practice in health professions education: a systematic review. Advances in health sciences education, 14(4), 595.

Mathers, S, Eisenstadt, N, Sylva, K, Soukakou, E, Erkey-Stevens, K (2014) Sound Foundations: A review of the research evidence on quality of early childhood education and care for children under three. London: The Sutton Trust. (January 2014).

MacNaughton, G. (2005) Doing Foucault in Early Childhood Studies. London: Routledge.Souto-Manning, M. \&

Morrison, K.R.B. (2009) Causation in Educational Research. London: Routledge.

National College for Teaching and Leadership (2017). Teaching school application guidance Cohort 12. NCTL November 2017.

Oberhuemer, P. (2013) Continuing professional development and the early years workforce. Early Years: An International Journal of Research and Development. (33). 2. 103-106.

Organisation for Economic Cooperation and Development. 2012. Starting Strong III. OECD January 2012.

Osgood (2010) Reconstructing professionalism in ECEC: the case for the 'critically reflective emotional professional' Early Years: An International Journal of Research and Development. (30). 2. 119-133.

Page, J. (2011). Do Mothers want professional carers to love their babies? Journal of Early Childhood Research 9: 310-323.

Page, J.,\& Elfer, P. (2013). The emotional complexity of attachment interactions in nursery, European Early Childhood Education Research Journal. 21:4, 553-567.

Panksepp, J. (2013). How Primary-Process Emotional Systems Guide Child Development.In Evolution, Early Experience and Human Development: From Research to Practice and Policy, edited by Narvaez, D., Panksepp, J., Schore, A.N. and Gleason, T.R. Oxford: Oxford University Press. 
Robson, S. (2011a). Producing and using video data in the early years: ethical questions and practical consequences in research with young children, Children and Society, 25(3): 179-89.

Robson, S. (2011b). Producing and using video data with young children: a case study of ethical questions and practical consequences, in Harcourt, D., Perry, B. \& Waller, T. (Eds.) Young Children's Perspectives: Ethics, Theory and Practice. Abingdon: Routledge.

Rustin, M.E. Some historical and theoretical observations. In Rustin, M.E. \& Bradley, J. (2008) (eds) Work Discussion: Learning from Reflective Practice in Work with Children and Families. London: Karnac books, p.12.

Rustin, M.E. \& Bradley, J. (2008) (eds) Work Discussion: Learning from Reflective Practice in Work with Children and Families. London: Karnac books.

Rustin, M.J. (2001). Reason and unreason. Psychoanalysis, science and politics. London: Continuum.

Shuttleworth, J.2002. "Turning towards a bio-psycho-social way of thinking". European Journal of Psychotherapy \& Counselling. 5(3). 205-223.

Siraj, I., Kingston, D. \& Melhuish, E. (2015) Sustained Shared Thinking and Emotional Well-being (SSTEW) Scale for 2-5-year-olds provision. London: Institute of Education.

Social Mobility Commission (2017). State of the Nation 2017. November 2017.

Sørensen, H.V. (2014) Ethics in Researching Young Children's Play. In Fleer, M \& Ridgway, A. (eds.) Visual Methodologies and Digital Tools for Researching with Young Children: Transforming Visuality. Cham, Switzerland: Springer.

Souto-Manning, M., Swick, K. J. (2006). Teachers' beliefs about parent and family involvement: Rethinking our family involvement paradigm. Early Childhood Education Journal, 34, 187-193.

Swick, K. 2004 'What parents seek in relations with early childhood family helpers' Early Childhood Education Journal, 31(3), 217-220.

Trevarthen, C. 2005. "Action and emotion in development of cultural intelligence: why infants have feelings like ours". In Emotional Development, edited by J. Nadel and D. Muir, 61-91. Oxford: Oxford University Press.

Urban, M, Vandenbroeck, M, Van Laere, K, Lazzari, A and Peeters, J (2012) Towards competent systems in Early Childhood Education and Care. Implications for Policy and Practice. European Journal of Education, 47(4), 508-526.

White, E.J. (2017) Video ethics and young children, Video Journal of Education and Pedagogy, 2:2. 
19| P a g e 